\title{
BUSINESS MODEL INNOVATION WITH PRECISION FARMING TECHNOLOGY FROM THE FARMERS POINT OF VIEW
}

\section{Author(s):}

E. Lencsés, K. Mészáros

\section{Affiliation:}

Szent István University, Faculty of Economics and Social Sciences, Páter K. u. 1., Gödöllö, H-2103, Hungary

\section{Email address:}

lencses.eniko@gtk.szie.hu, meszaros.kornelia@gtk.szie.hu

\begin{abstract}
Agricultural holdings try to survive in the fast-changing word. The agricultural production goes throw several revolutions. These revolutions motivated companies to change their business models. The digital revolution going on nowadays. Digital agriculture has emerged as a way of feeding the world sustainably using technologies and data science to optimise on-farm production and supply chains that are responsive to real-time consumer demand. The aim of this paper to identify the changes in business model by precision farming technology. The new production methods give a chance to the agricultural holdings to make ability to take advantage of new opportunities and face with the modern challenges and new requirements.
\end{abstract}

Keywords: digital revolution, farming 3.0, business strategy, business models, precision farming

\section{Introduction}

Numerous global trends are influencing on agribusiness. Agricultural production needs face with the following main challenges: growing population, increasing urbanization, climate change, technology change. Modern agricultural holdings try to survive in the fast-changing word. Modern food systems face the growing challenges of climate variability, population growth, and ever-changing consumer preferences. Modern farms will work differently than the farms in the last decades. The new agricultural equipment use sensors and information technology. Future agriculture will use sophisticated technologies such as robots, temperature and moisture sensors, aerial images, and GPS technology. The researchers call this kind of change agricultural revolution which let farms be more profitable, efficient, safer, and environmentally friendly. Otherwise, in social-level the demand for the fork-to-fork monitoring of plant production is increasing. With precision farming technology, huge amount of information could be realized about the production process. The society requires the decreasing of environmental damage, ecological sustainability. Both demand make true with precision farming technology (Lencsés, 2016). We are in the middle of new agriculture revolution. The stages of the agriculture are the following (Kovács - Husti, 2018; Lejon - Frankelion, 2015; Popp et al., 2018; Rose - Chilvers, 2018; Varga, 2018), (Figure 1):

1. Labour-intense agriculture: low productivity, enough food for population and the $1 / 3$ of the population needed to work in the agriculture.

2. Green revolution: the adoption of new technologies such as yield variety, chemical fertilizers, agrochemicals, irrigation, new methods of cultivation, including mechanization. The key leader was Norman Borlaug.

3. Digital revolution / Precision farming: variable rate technology, site specific decision, GIS, GPS

4. Smart farming: big data, cloud based, on-line sensors, UAV

5. Robotic farming: robots use in agriculture production e.g. spraying drones, weed-management robots. These technologies are still under development. 


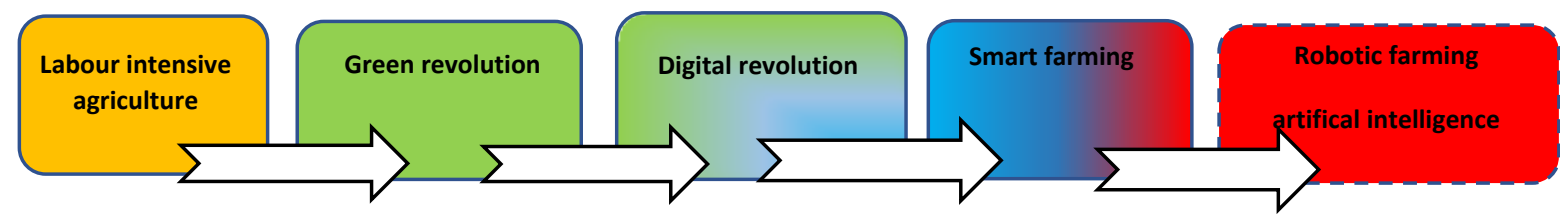

Figure 1. Technology revolutions in agriculture production, Own structured based (Kovács - Husti, 2018; Lejon - Frenkelius, 2015; Popp et al., 2018; Rose - Chilvers, 2018; Varga, 2018)

The green revolution has brought to over-cultivation and excessive chemical usage, which has contributed to land degradation and great harms of natural ecosystems. This episode leading to the need of sustainable resource management. The third industrial revolution leads to the digital revolution in the agriculture. Precision farming which is also knows as satellite farming or site specific crop management is the part of digital revolution. The goal of precision farming technology is to optimizing returns on inputs while preserving resources. There is no one exact definition of precision farming technology because these technology is still under development mostly in case of sensors and variable rate technology (VRT). This paper uses the definition on the basis of the European Parliamentary Research Service (2016): 'precision farming, is a modern farming management concept using digital techniques to monitor and optimise agricultural production processes. Rather than applying the same amount of fertilisers over an entire agricultural field. It will measure variations in conditions within a field and adapt its fertilising or harvesting strategy accordingly. Precision farming has several synonyms (Tamás, 2001): site specific production/technology, spatial variable technology, spatial decision supporting system, satellite farming. The smart farming is the development of original precision farming technology (the ideology behind the field production is the same). Romeo (2016) was the first use of the 'Smart farming' terminology. Smart farming is include smart control devices (on-board computers), sensors for agronomic process, automation capabilities (guidance, seed placement, spraying, etc, communication technology (telematics). Smarter machines should use the minimum amount of energy to turn the natural environment into useful agriculture, thus cutting out wasted energy and reducing costs (Blackmore, without year). According to the representative research of Research Institute of Agricultural Economics in 2016 among the Hungarian farmers only 7\% used any type of precision farming technology, the majority of the Hungarian farmers still have been only in the 'Green revolution' stage. Only $15 \%$ of the precision farmers who used any kind of on-line sensors which could be the base of Smart farming (Kemény et al., 2017). Business model is a concept which has been widespread in business and management sciences since 1990s (Lambert - Davidson, 2012). The focus of the concept is the business logic; as it elaborates what a business actually does and how it makes profit. This concept is related to the creation and deliver of value by a company. According to Magretta (2002) business models are like stories illustrating how an organization work.

Osterwalder et al. (2005) provide a model to design and analyse the business model. This model includes four pillars: 1) product/service, 2) customer interface, 3) infrastructure management, and 4) financial aspects. According to this model, to analyse the pillar of product/service, the value proposition of the business should be analysed. Value proposition is defined as an overall view of a company's bundle of products and services (Ostelwalder et al., 2005). To analyse the pillar of customer interface, three sub-variables should be studied (target customer, distribution channel, and relationship). The target customer is the segments of customers a company wants to offer value to. Distribution channel is considered as the various means of the company to get in touch with their customers. And finally, relationship explains the kind of links a company establishes between itself and its different customer segments. Osterwalder et al. (2005) express that value configuration, core competency, and partner network are the representative of infrastructure management. In this model, value configuration describes the arrangement of activities and resources. Core competency outlines the competencies necessary to execute the business model. Partner network portrays the network of cooperative agreements with other companies necessary to efficiently offer value.

The last pillar of this model is the financial aspects. This pillar contains cost structure and revenue model. Cost structure sums up the monetary consequences of the means employed in the business model. And revenue model describes the way a company makes money through a variety of revenue flows. Decision makers select their business model based on strength, weakness, environmental opportunities and threats. The business models of competitors could be completely different. Competitor who selects the best model and implements it effectively can win the trade and competition. 
Osterwalder et al. (2005) discuss the identification of this area is the main step to keep in state of art and to make timely changes. In other word a business model not only helps managers to identify the current situation of each mentioned areas, but also it helps to track the trends and respond dynamically to the transitions. Different reasons force the organizations to change their previous business model. Investments and innovations, information systems, human capital, new technologies are some from the lots of examples of business model innovation driving forces. Hence to respond to these changes the businesses must reconsider their business model. Of course, the aim of agility is not just inactively responding to the environment changes, it is also considered as taking advantages of changes (Dove, 1994; Kidd, 1994; Sharifi - Zhang, 1999).

Innovation in a business model is not simply mean the innovation in services/products or technology (Lindgadt et al., 2009; Massa - Tucci, 2013; Mitchell - Bruckner, 2004). Lindgardt et al. (2009) believe that when innovation in business model is happened that at least two components are reinvented and innovation in just product/service does not count as a business model innovation. According to them the two main parts of the business model are the value proposition model and the operating model. Value proposition model includes following components: target segment, products/services offering, revenue model, operating model, comprises value chain, cost model, and organization. Lindgardt et al. (2009) discuss that since a business model is a multidimensional system changing in more than two of its components leads to changing the whole of the model and it is business model innovation. Whiles, Mitchell and Bruckner (2004) argue that innovation in at least four business model components leads to business model innovation which enables the company to offer new products/service to new segments of the market. Nevertheless, innovation in business model has been always recommended, due to the sustainable competitive advantage is created in business model innovation (Giesen et al., 2007; Mitchell - Bruckner, 2004). Massa and Tucci (2013) also argue that business model innovation consists innovation in content, structure and governance. Amit and Zott (2012) discuss that innovating a business model is usually taking place in three ways: set up a new activity, connecting the activities in new ways, and changing the parties carry out an activity. They need to dynamically trace the trends and to have a proper change management to be able response on time to these changes (Mitchell - Bruckner, 2004). Of course, the aim of agility is not just inactively responding to the environment changes, it is also considered as taking advantages of changes (Sharifi \& Zhang, 1999; Dove, 1994; Kidd, 1994).

\section{Methodology}

In case of farmers who want to use precision farming technology there is no standard practice for how the application of the new technology will change their business model (both in the developed agricultural producing countries both in the weaker agriculture countries). This paper wants to give a framework for the farmers how they think about their business model with precision farming technology. In the literature background the development of agricultural technologies and the business model innovation were studied. The aim of this paper to fit to the adaptation of precision farming technology in the business model innovation theory which based on Lindgardt et al. (2009). This case study identifies the competitive advantages of the precision farming technology in the business model point of view.

According to Lindgardt et al. (2009) the business model innovation examined with the following factors:

- Target segment: Which customers do we choose to serve? Which of their needs do we seek to address?

- Product offering: What are we offering the customers to satisfy their needs?

- Revenue model: How are we compensated for our offering?

- Value chain: How are we configured to deliver on customer demand?

- Cost model: How do we configure our assets and costs to deliver on our value proposition profitably

- Organization: How do we deploy and develop our people to sustain and enhance our competitive advantage?

\section{Results and discussion}

Time by time the changes of business models are necessary. For examples because of an investment or innovations e.g. new technology or Enterprise Resource Planning systems goes together with strategic and business model changes. However, the flexibility of agricultural holdings is not limited to specific changes 
in the environment reactions, the main objective should be the competitive advantages resulting from changes (Dove, 1994; Kidd, 1994; Sharifi - Zhang, 1999).

Table 1: Changes of business model element by Lindgardt et al. (2009) thanks to the adaptation of precision farming technology

\begin{tabular}{|c|c|c|}
\hline $\begin{array}{c}\text { Components of business } \\
\text { model }\end{array}$ & CONVETIONAL FARMING & PRECISON FARMING \\
\hline \multirow{2}{*}{ TARGET SEGMENT } & $\begin{array}{l}\mathrm{B} 2 \mathrm{C}^{1} \text { : people who wants to consume } \\
\text { fresh agricultural products }\end{array}$ & $\begin{array}{l}\text { B2C: fresh agricultural } \\
\text { product's consumers who want } \\
\text { to tracing a food and who has a } \\
\text { moderate environmental } \\
\text { friendly attitude }\end{array}$ \\
\hline & $\begin{array}{l}\mathrm{B}^{2} \mathrm{~B}^{2} \text { : business at the food industry } \\
\text { who looks for raw materials }\end{array}$ & $\begin{array}{l}\text { B2B: business at the food } \\
\text { industry who looks for raw } \\
\text { materials and for whom the } \\
\text { comprehensive system of } \\
\text { traceability is very important }\end{array}$ \\
\hline PRODUCT OFFERING & $\begin{array}{l}\text { Agricultural products e.g. crops, } \\
\text { vegetables, fruits. }\end{array}$ & $\begin{array}{l}\text { Agricultural products e.g. crops, } \\
\text { vegetables, fruits. }\end{array}$ \\
\hline REVENUE MODEL & $\begin{array}{l}\text { In the agriculture price and yield } \\
\text { volatilities are general because of the } \\
\text { high-risk factors. }\end{array}$ & $\begin{array}{l}\text { With precision farming } \\
\text { technology the yield volatilities } \\
\text { become less general because of } \\
\text { the more rational input usage. }\end{array}$ \\
\hline VALUE CHAIN & $\begin{array}{l}\text { Whole range of goods and services } \\
\text { necessary for an agricultural product to } \\
\text { move from the farm to the final } \\
\text { customer or consumer. }\end{array}$ & $\begin{array}{l}\text { The members of the value chain } \\
\text { is the same than in case of } \\
\text { conventional agricultural } \\
\text { production. The difference that } \\
\text { less chemicals are used with } \\
\text { precision farming technology. } \\
\text { The rational chemical usage } \\
\text { could be a tool for enhancing } \\
\text { consumer confidence in the } \\
\text { agricultural products. The } \\
\text { distribution is not changed. }\end{array}$ \\
\hline COST MODEL & $\begin{array}{l}\text { According to FADN cost structure the } \\
\text { costs linked to the agricultural activity } \\
\text { of the holder and related to the output } \\
\text { of the accounting year. } \\
\text { Included: crop-specific inputs, total } \\
\text { farming overhead, depreciation of } \\
\text { capital assets estimated at replacement } \\
\text { value, total external }\end{array}$ & $\begin{array}{l}\text { The cost model is the same than } \\
\text { in the conventional farming } \\
\text { methods. We need to recalled } \\
\text { that the investment of the } \\
\text { precision farming technology is } \\
\text { higher than of the conventional } \\
\text { equipments. }\end{array}$ \\
\hline ORGANIZATION & $\begin{array}{l}\text { Generally, the staff of the agricultural } \\
\text { holdings is not well qualified or well } \\
\text { educated }\end{array}$ & $\begin{array}{l}\text { The precision farming } \\
\text { technology is very sensitive to } \\
\text { the digital skills of the staff and } \\
\text { management. The management } \\
\text { commitment of technology is } \\
\text { very important factor in case of } \\
\text { the new modern technology }\end{array}$ \\
\hline
\end{tabular}

Source: own research

${ }^{1} \mathrm{~B} 2 \mathrm{C}$ (Business-to-Customer): process of selling products and services directly between consumers who are the endusers of its products or services

${ }^{2}$ B2B (Business-to-Business): situation where one business makes a commercial transaction with another business 
Table 1. presented the main factors of business model in case of conventional and precision farming technology.

Precision farming is also in line with the EU's long-term potential, as set out in the Green Deal Farm to fork initiative. In this, it is strategically important to write crop pests and pathogens in a safe, alternative way. It also aims to make food raising healthier and more environmentally friendly. This preserves the conservation of biodiversity and the protection of the health and well-being of citizens against environmental risks and impacts (Eurpoean Commission, 2020).

\section{Conclusion}

The adaptation of precision farming technology gives a lot of competitive advantage for the farmers. Thanks to the lots of data about the filled and yield the precision farmers could give a chance to better monitoring and tracing for their buyers. The traceability (fork-to-fork thinking) is becoming more important in case of food processing and consumption. There is no change in the form of products but the quality and quantity of it is higher. Thanks to the input optimisation by zones the production risks are lower than with conventional farming and the yield (quality and quantity) are stable. The site-specific input application contributed on risk reduction and also leads to a less environment harmful production which becomes more and more important for the food customers. The big data in the agricultural production enabling the fork-to-fork monitoring. The type of cost is not changed. But the input cost could be decrease and the machinery cost could be increased in the same time with precision farming technology. The precision farming technology used expensive and IT based machineries so the efficient usage of the equipment are more important otherwise the technology could not be profitable. The technology is sensitive for the skills of staff.

\section{References}

[1] Amit, R.; Zott, C. (2012): Creating value through business model innovation. MIT Sloan Management Review, Vol. 5. No. 3. 41-44.

[2] Blackmore S.: Farming with robots. Letöltés dátuma: 2019. 12. 02, Source: SPIE Newsroom: http://spie.org/newsroom/blackmore-video

[3] European Commission (2020): Research and innovation for the European Green Deal, https://ec.europa.eu/info/research-and-innovation/strategy/european-green-deal_en

[4] Farm Accountancy Data Network (FADN): https://circabc.europa.eu/sd/a/16d411ec-33fe-404b-ab4cefcfdbbf9935/RICC\%20882\%20rev9.2\%20Definitions\%20of\%20Variables

[5] Dove, R. (1994): Agile and otherwise, series of articles on agile manufacturing. Production Magazine, november.

[6] European Parliamentary Research Service - Scientific Foresight Unit (STOA).:2016. Precision agriculture and the future of farming in Europe. Study. Brussels. http://www.europarl.europa.eu/RegData/etudes/STUD/2016/581892/EPRS_STU(2016)581892_EN.pd $\mathrm{f}$

[7] Giesen, E.; Berman, S. J.; Bell, R.; Blitz, A. (2007): Three ways to successfully innovate your business model. Strategy \& Leadership, Vol. 35. No. 6. 27-33. https://doi.org/10.1108/10878570710833732

[8] Kemény G.; Lámfalusi I.; Molnár A. (edit); Gaál M.; Kiss A.; Péter K.; Sulyok D.; Takács György K.; Domán Cs.; Illés I.; Kemény Horváth Zs. (2017): A precíziós szántóföldi növénytermesztés összehasonlító vizs-gálata $=$ Comparative study of precision arable crop production. Agrárgazdasági Könyvek. Agrárgazdasági Kutató Intézet, Budapest. ISBN 978-963-491-601-7 http://repo.aki.gov.hu/2488/1/2017_K_03_Precizios_konyv_web_pass.pdf

[9] Kidd, P. T. (1994) Agile Manufacturing: Forging New Frontiers. Addison-Wesley, WokinghamReading, MA.

[10] Kovács I.; Husti I. (2018): The role of digitalization in the agricultural 4.0 - how to connect the industry 4.0 to agriculture? Hungarian Agricultural Engeneering, Published online: http://hae-journals.org/ ISSN 2415-9751 doi: 10.17676/HAE.2018.33.88

[11] Lambert, S. C.; Davidson, R. A. (2012): Applications of the business model in studies of enterprise success, innovation and classification: An analysis of empirical research from 1996 to 2010. European Management Journal, Vol. 31. No. 6. 668-681.

[12] Lejon E.; Frankelius P. (2015) Sweden innovation power-Agritechnica 2015, Elmia, Jönköping, Sweden. https://www.academia.edu/28862722/Sweden_Innovation_Power_Agritechnica_2015 
[13] Lencsés E. (2016): agricultural innovation and site specific farming, In: Felicjan, Bylok; Anita, Tangl (szerk.): The role of management functions in successful enterprise performance. Budapest, Magyarország: Agroinform Kiadó, (2016) pp. 61-70., 10 p.

http://real.mtak.hu/39383/1/Role_of_Management_Functions-2016okt05-DOI_CrossRefChapter_1.5.pdf

[14] Lindgardt, Z.; Reeves, M.; Stalk, G.; Deimler, M. S. (2009): Business Model Innovation. When the Game Gets Tough, Change the Game. The Boston Consulting Group, Boston, MA. https://doi.org/10.1002/9781119204084.ch40

[15] Magretta, J. (2002): Why Business Model Matter. Harvard Business Review, Vol. 80. No. 5. 86-92.

[16] Massa, L.; Tucci, C. L. (2013): Business model innovation. The Oxford Handbook of Innovation Management, 420-441. https://doi.org/10.1093/oxfordhb/9780199694945.013.002.

[17] Mitchell, D. W.; Bruckner Coles, C. (2004) Business model innovation breakthrough moves. Journal of Business Strategy, Vol. 25. No. 1. 16--26. https://doi.org/10.1108/02756660410515976.

[18] Osterwalder, A.; Pigneur, Y.; Tucci, C. L. (2005): Clarifying business models: Origins, present, and future of the concept. Communications of the association for Information Systems, Vol. 16. No. 1. https://pdfs.semanticscholar.org/4d60/687583e42658fa1c47c9a a02813ce428da4b.pdf.

[19] Popp J.; Erdei E.; Oláh J. (2018): A precíziós gazdálkodás kilátásai Magyarországon (Outlook of precision farming in Hungary); International Journal of Engineering and Management Sciences (IJEMS) Vol. 3. No. 1 DOI: 10.21791/IJEMS.2018.1.15.

[20] Romeo S.: 2016. Enabling Smart Farming through the Internet of Things Current Status and Trends. Principal Analyst -Beecham Research, Sensing Technologies for Effective Land Management Workshop, Bangor http://www.nrnlcee.ac.uk/documents/5.SaverioRomeoSmartFarming.pdf

[21] Rose D. C.; Chilvers J.: 2018. Agriculture 4.0: Broadening responsible innovation in an Era of Smart faming; Frontiers in Sustainable Food Systems; doi: 10.3389/fsufs.2018.00087 https://www.frontiersin.org/articles/10.3389/fsufs.2018.00087/full

[22] Sharifi, H.; Zhang, Z.: 1999. A methodology for achieving agility in manufacturing organisations: An introduction. International Journal of Production Economics, Vol. 62. No. 1. 7-22. https://doi.org/10.1016/S0925-5273(98)00217-5.

[23] Tamás J. (2001): Precíziós mezőgazdaság elmélete és gyakorlata, Szaktudás Kiadóház, 144 p.

[24] Varga P. (2018): Stratégiai beavatkozási rendszer, https://www.slideshare.net/iier/digitlis-agrrstratgia-beavatkozsi-rendszere 